\title{
Ant community structure and response to disturbances on coastal dunes of Gulf of Mexico
}

\author{
Xuan Chen · Benjamin Adams $\cdot$ Cody Bergeron • \\ Alexander Sabo $\cdot$ Linda Hooper-Bùi
}

Received: 2 December 2013/Accepted: 31 October 2014/Published online: 10 December 2014

(C) The Author(s) 2014. This article is published with open access at Springerlink.com

\begin{abstract}
Coastal dunes are complex and fragile ecosystems. The decrease in environmental stressors from sea to inland creates zonation patterns of habitats, which support high biodiversity. Although coastal dunes have been examined in primary succession studies for more than 100 years, invertebrates have received much less attention than other taxa. In this study, we examined ant community composition and its relationship with vegetation structure on dunes, and used ants as indicators to reveal the influence of anthropogenic disturbances on these habitats. Quadrat sampling, hand collecting, and beating plants were used to sample ants on coastal dunes fringing the northern Gulf of Mexico. Ants representing 44 species were found, with diversity and number of functional groups increasing from foredunes to backdunes. Bush areas of the backdunes supported a unique ant community. Ant diversity was correlated with plant richness, stem number, and plant cover, but the correlation was not consistent among habitats. Ant diversity was lower in degraded, young-planted, and re-built but not in old-planted sites. In addition,
\end{abstract}

X. Chen $\cdot$ B. Adams $\cdot$ A. Sabo $\cdot$ L. Hooper-Bùi $(\bowtie)$ Department of Entomology, 404 Life Science Building, Louisiana State University, Baton Rouge, LA 70803, USA e-mail: Lindabui@1su.edu

B. Adams

Department of Biology, 139 Life Science Building, University of Louisville, Louisville, KY 40292, USA

C. Bergeron

Department of Biological Sciences, College of Science, Louisiana State University, Baton Rouge, LA 70803, USA

L. Hooper-Bùi

School of the Coast and Environment, Louisiana State University, Baton Rouge, LA 70803, USA different types of disturbance changed the ant community and functional groups in different ways. Our study emphasizes the importance of protecting the whole dune system, especially the backdunes, which support high diversity but are often completely destroyed by urban development. Data from this research provides a benchmark to examine trajectories of coastal dune ecosystem degradation or recovery when exposed to natural or anthropogenic disturbances.

Keywords Formicidae - Vegetation structure $\cdot$ Habitat complexity · Functional groups · Disturbance - Dune restoration

\section{Introduction}

Coastal dunes have a worldwide distribution and protect areas further inland from erosion by waves and wind (David Jr and Fitzgerald 2004). Dunes support high ecological diversity and contain many endemic and endangered species due to their geomorphological and environmental heterogeneity (Powell 1981; Lichter 1998; Van der Maarel 2003). However, they are fragile ecosystems and suffer from many kinds of natural and anthropogenic disturbance including hurricanes, invasive species, global sea-level rise, urbanization, and improper management (Feagin et al. 2005; Grunewald 2006; El Banna and Mahmoud 2008; Bonte and Maes 2008; Claudino-Sales et al. 2008; Marchante et al. 2008; Jackson and Cooper 2011; Provoost et al. 2011).

Distinguishing characteristics of these areas are the environmental and vegetation gradients that run perpendicular to the seashore and create discrete, parallel zones of habitation in a relatively small area (Hesp 1991; Dech and 
Maun 2005; Lane et al. 2008). Each zone has its own plant composition that is able to withstand the biotic and abiotic stressors in that given area (Wilson and Sykes 1999; Maun 2009; Miller et al. 2010). Generally, a few herbaceous pioneer plants dominate the foredunes; backdunes yield higher diversity with woody species becoming more abundant (Kerley et al. 1996; Maun and Perumal 1999; Isermann 2011; Mondino et al. 2011). Decreased physical stress and more complex vegetation structure in the backdunes create more available habitats. As a result, faunal diversity and complexity of food webs increase with distance from the ocean (Gaylard et al. 1995; Slawska 1997; Yoshitake and Nakatsubo 2008; Rajaniemi and Allison 2009). Coastal dunes have often been used in primary succession studies to examine changes of diversity and community composition, and species replacement (Duffy 1968; Boomsma and Van Loon 1982; Johnson 1997). However, rates of succession and responses to the various gradients are not the same for different groups of organisms (Slawska 1997; Bonte et al. 2004; Isermann 2005; Lane et al. 2008). Compared to the well-studied soils and plant succession, much less is known about invertebrate changes not only in coastal dunes, but also in other primary succession sites (Kaufmann 2001).

Ants (Hymenoptera: Formicidae) are among the most numerically abundant creatures in nature, but have received much less attention than plants, spiders, birds, mammals, and soil microorganisms on coastal dunes. However, ants play important ecological functions in these ecosystems. For example, they act as soil engineers by affecting soil lime content, thickness of the organic layer, and compactness (Bonte et al. 2003); they compete for food with crabs and other arthropods (Morrison 2002); disturb turtle nests (Wetterer et al. 2007); decrease the herbivore population (Oliveira et al. 1999; Lehouck et al. 2004); transport seeds, and influence plant germination, reproductive success, and distribution patterns (Oostermeijer 1989; Bonte et al. 2003; Cuautle et al. 2005). They also engage in many mutualistic associations with other creatures (Crutsinger and Sanders 2005; Rico-Gray et al. 2007). Therefore, given that few studies have investigated ants on coastal dunes-none along the northern Gulf of Mexico-the first step of this research was to characterize ant diversity, community structure, and how environmental factors, especially vegetation structure, influence ants on dunes.

Moreover, ants have numerous attributes that make them ideal bioindicators: they have a worldwide distribution, high diversity and abundance (Hölldobler and Wilson 1990), there is a good taxonomic- and biologicalknowledge base, and they are easy and cost effective to sample (Agosti et al. 2000). Their diversity also strongly corresponds with that of other organisms (Majer 1983;
Andersen et al. 1996; Schuldt and Assmann 2010). Furthermore, they are sensitive to habitat modification and respond to changes in ways similar to other taxa (King et al. 1998; Hoffmann et al. 2000; Andersen et al. 2002; Hoffmann and Anderson 2003; Andersen et al. 2004). All of these factors make ants useful surrogates for measuring progress or success of conservation plans and in environmental monitoring programs that aim to maintain or restore the ecological integrity of the ecosystem. Although the importance of the restoration of disturbed coastal dunes has long been recognized, most of the management and evaluation efforts have focused on geomorphology and vegetation, with less attention given to animals in these conservation actions (Lithgow et al. 2013). In the second part of this research, we addressed how the loss of backdunes affects ant communities, and used ants as indicators to study the influences of restoration activities on dunes.

\section{Methods}

Study sites

We established ten sampling sites along the northern coast of the Gulf of Mexico (Fig. 1). This region is characterized as a temperate to sub-tropical climate heavily influenced by storm surge and hurricanes.

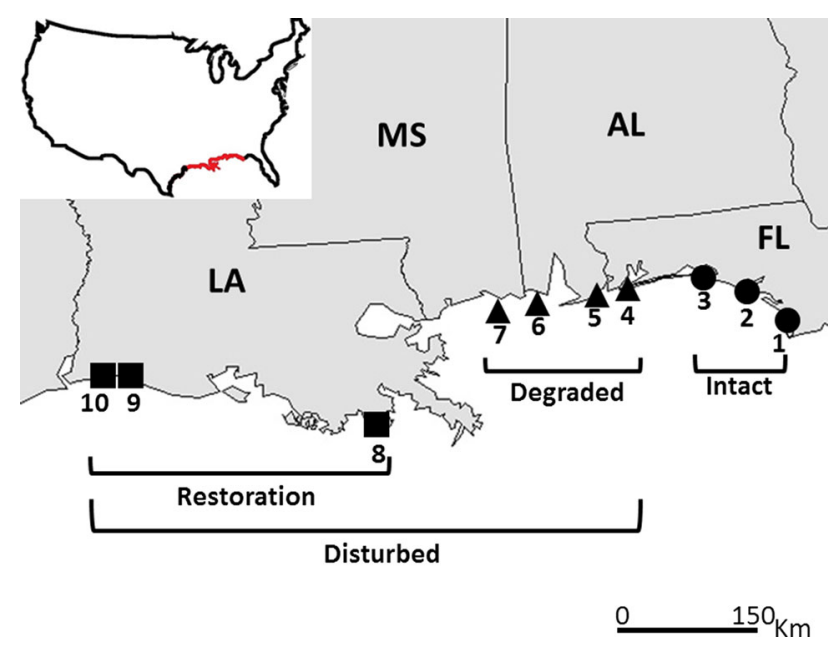

Fig. 1 Location of study sites along northern Gulf of Mexico [red line (online colour version only) in the contiguous US map shows the range of study sites]. 1 Saint Joseph Peninsula Preserve State Park, 2 Saint Andrews State Park, 3 Grayton Beach State Park, 4 Big Lagoon State Park, 5 Gulf State Park, 6 Dauphin Island, 7 Ship Island, 8 Grand Isle (young and old planted dunes), 9 Cameron Beach (re-built dunes), and 10 Mae's Beach (young planted dunes) 


\section{Intact dunes}

Saint Joseph Peninsula Preserve State Park, Saint Andrews State Park, and Grayton Beach State Park are well protected from human disturbance and contain foredunes, slacks, and backdunes. These sites we labeled as intact dunes. Intact coastal dune systems consist of distinct plant communities that we divided into four habitats: foredunes, slacks, open ground of backdunes, and bush areas of backdunes (Fig. 2a, b). The first three are open areas dominated by herbaceous species such as Ipomea stolonifera J. F. Gmel, Panicum amarum Elliott, Uniola paniculata L., and Paspalum vaginatum Sw. Bush areas of the backdunes are shady due to the occurrence of Quercus geminate Small.

\section{Disturbed dunes}

Big Lagoon State Park, Gulf State Park, Dauphin Island, and Ship Island no longer contain slacks and backdunes. Because of this, we labeled these sites as degraded dunes (Fig. 2c). The foredunes on these sites were well protected but are surrounded by areas of high human disturbance (tourist beaches, roads, and buildings). Dunes in Louisiana are poorly developed due to the high frequency of disturbances caused by hurricanes and storm surges. P. amarum Elliott (bitter panicgrass) was planted in some areas of Grand Isle and Mae's Beach to restore the dunes, and as such were labeled as planted dunes (Fig. 2d, areas planted less than
3 years before the time of study were called young-planted sites - found in both Grand Isle and Mae's Beach, sites more than 6 years old were termed old-planted sites-present only in Grand Isle). Most of Cameron Beach (very close to Mae's Beach) was re-built 3 years ago (2010) prior to the study, and was labeled as re-built dunes (Fig. 2e). Planted and re-built areas were also called restoration dunes. In restoration areas, we chose the dunes located in State Parks or wildlife refuges as the references to evaluate how restoration actions affect ants (Landi et al. 2012).

Sampling methods and environmental information

Quadrat sampling and hand collecting were the primary methods we used in this study due to the large variation of vegetation structure of each habitat. Pitfall traps and baiting, the most common collection methods in invertebrate studies, could not be used because setting baits and digging are forbidden on coastal dunes in addition to the problem of disturbance due to tides and shifting sands. Winkler funnels, another common method, were not suitable because no leaf litter occurs in foredunes and slacks.

We created transects along the foredune, slack, and open ground of the backdunes in intact dunes, but only along the foredune in disturbed dunes. Each transect, which was parallel to the shoreline, was composed of seven to ten plots $(0.6 \mathrm{~m} \times 0.6 \mathrm{~m}$ quadrats) separated by at least $10 \mathrm{~m}$. Variations in total number of plots per transect were due to time limitations (explained below). If an ant nest or foraging trail
Fig. 2 a Schematic representation of intact coastal dunes. b Coastal dunes in Saint Joseph Peninsula Preserve State Park, Florida. 1 Foredune, 2 slack, 3 backdune (open ground), and 4 backdune (bush). c Foredune in Gulf State Park. d Planted dune in Grand Isle. e Re-built dune in Cameron Beach

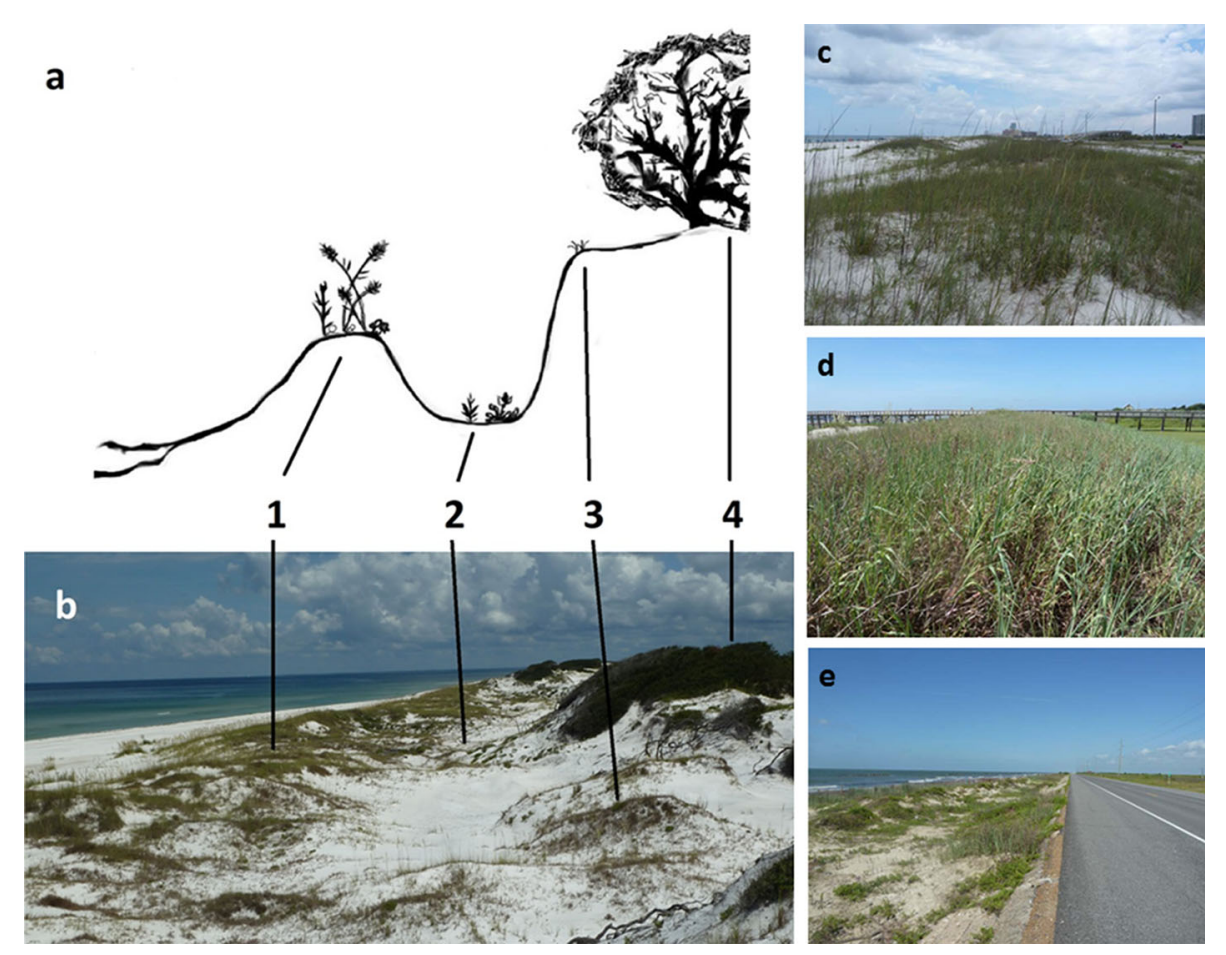


was found within $1.5 \mathrm{~m}$ of a plot location, that plot was not used. All ants on the ground or on the plants within the quadrat were collected by aspirator and stored in $95 \%$ ethanol, which would take about $1 \mathrm{~min}$. Environmental factors that may influence ant presence were also measured. These included time of day, temperature, relative humidity, and plant structure (species, stem number, maximum and average height, and presence of flowers). A photograph from $1 \mathrm{~m}$ above the quadrat was also taken to determine percent vegetation coverage in each plot. All sampling occurred between 8:00 am and 12:00 pm to standardize collection and reduce variation due to time or temperature differences. Opportunistic hand collecting was conducted for $1 \mathrm{~h}$ in each habitat after all quadrat sampling was complete.

We selected plots in the bush areas based on the presence of leaf litter and canopy cover, as well as isolation from surrounding bushes (eight plots in Saint Joseph Peninsula Preserve State Park, six in Saint Andrews State Park, and five in Grayton Beach State Park). A quadrat sample $(0.6 \mathrm{~m} \times 0.6 \mathrm{~m})$ was taken at each plot. Temperature, relative humidity, and leaf litter depth (at each corner and the middle of the quadrat) were recorded. All leaf litter within the quadrat was then transferred to a plastic container to prevent ants from escaping. An initial inspection for ants was conducted on the leaf litter. Any ants seen in the leaf litter were immediately collected. The leaf litter was then sifted in small batches through a mesh screen $(0.5 \mathrm{~cm} \times 0.5 \mathrm{~cm})$ into a different plastic container. All ants from the sifted leaf litter were collected and stored in $95 \%$ ethanol. The quadrat sampling under the bush would take about 1.5-2 h per plot. The leaf litter was then stored in a plastic bag and taken back to the lab for further analysis including measuring dry weight and determining the number of species of plants represented by the leaves in the sample. Information about vegetation structure (distance from center of quadrat to the three nearest bushes, the circumference of bush trunks, and the height of the lowest live branch) was then documented. We also performed opportunistic hand-collecting and beating on and around bushes on the backdune.

Data analysis

\section{Intact dunes}

We generated rarefaction and extrapolation curves to compare ant species richness among foredune, slack, open ground of the backdune, and area under the bushes in the backdune using EstimateS (Colwell 2013; we extrapolated the number of samples in each habitat to 42 based on Chao 2). Data from quadrat sampling and hand collecting were pooled to maximize species richness (Gotelli and Ellison 2012). Richness was also compared among the four habitats using analysis of variance (ANOVA) in SAS 9.3
(PROC GLIMMIX). To assess sampling completeness, incidence-based coverage estimator (ICE) and Chao 2 were calculated for each habitat using EstimateS. Rényi diversity profiles were performed using Biodiversity R (Kindt and Coe 2005; R Core Team 2013) to study the differences of diversity among habitats. The Rényi profile is a useful method for diversity ordering, and can provide more information than single a diversity index (Tóthmérész 1995; Ricotta 2003; Kindt et al. 2006). In the profile, each line represents the diversity of one habitat; the higher position of the line represents the higher diversity of that habitat. It is not possible, however, to order the diversity when the lines intersect. Ant species were assigned to functional groups as described by Andersen (1997) and Hoffmann and Anderson (2003).

Patterns of species composition of ant assemblages were investigated using multivariate analysis with Program PAST (Hammer et al. 2001). We conducted a twodimensional ordination with Detrended Correspondence Analysis (DCA) and non-metric multidimensional scaling (NMDS) to assess the species composition among habitat plots, and then performed Analysis of Similarities (ANOSIM) to detect the differences of composition among sites. Only presence/absence data was used to do the above analysis (Gotelli et al. 2011).

Ant richness, relative abundance (individuals per quadrat), and vegetation structure (open area: plant richness, stem number, plant cover, maximum and average stem height, and flowering or not; bush area: litter depth, litter dry weight, distance between quadrat to closest bush, trunk circumference of that bush, and canopy height) were analyzed using multiple linear regression in SAS (PROC REG). Both backward and forward selections were used to determine the most closely related vegetation variables. Ant species richness and relative abundance, plant richness and stem number were log-transformed before analysis to ensure normal distribution.

\section{Disturbed dunes}

Rényi diversity profiles, functional groups, and ANOSIM were used to study the effects of disturbances on ant communities (intact vs. degraded dunes, and reference vs. restoration sites).

\section{Results}

Species diversity, community structure, and functional groups in intact dunes

A total of 3,854 individuals (1,595 from quadrat sampling and 2,289 from hand collecting) representing 44 species, 
24 genera, and 6 subfamilies were collected (Table 1). The richest subfamily was Myrmicinae, which included 23 species from 12 genera. Species richness per habitat was $6,6,9$, and 39 in foredunes, slacks, open ground of backdunes, and backdunes under bushes, respectively. Rarefaction and extrapolation curves approached an asymptote for open (foredunes, slacks, and open ground of backduness) but not for bush areas (Fig. 3). The ICE and Chao 2 also estimated that we collected the majority of ants in the open areas. However, six to nine species may have been missed in/under bushes (Table 2). Species richness under bushes was significantly higher than that in other habitats (ANOVA, $\mathrm{F}_{3,70}=13.30, \quad d f=3$, $P<0.0001$ ), but was similar among open areas. In addition, the Rényi profile indicated bush areas supported the highest diversity, followed by the open ground of backdunes (Fig. 4). The most numerous species in open areas were Dorymyrmex flavus McCook and Forelius pruinosus (Roger). Pheidole dentata (Mayr) was the most common ant under the bushes of the backdunes, followed by Trachymyrmex septentrionalis (McCook) and Aphaenogaster ashmeadi (Emery). The least abundant species across all of our research sites were Aphaenogaster floridana Smith, Stigmatomma pallipes (Haldeman), and Temnothorax texanus (Wheeler), each represented by fewer than five individuals.

DCA and NMDS produced similar results, and only the DCA analysis is shown here. The graph showed two distinct ant communities (Fig. 5). Plots of foredunes, slacks and open ground of backdunes overlapped (but the dots of open ground of backdunes were closer to that of bush). Plots of bush area separated from that of open areas. One-way ANOSIM further confirmed that the species composition of bush areas is significantly different from other habitats (Jaccard Index, $\mathrm{R}=0.2882$, $P<0.0001)$.

Eight of Andersen's functional groups were found in our research sites (Table 1). These included Dominant Dolichoderinae (one species), Subordinate Camponotini (3), Generalized Myrmicinae (7), Tropical Climate Specialists (5), Hot Climate Specialists (1), Cold Climate Specialists (2), Opportunists (14), and Cryptic Species (10). We placed Solenopsis invicta Buren in a new functional group: Dominant Invasives, and placed Pheidole moerens (Wheeler) in Cryptic Species based on their biological characters such as body size, limited interactions with other ants, and personal communication with Dr. Allen Andersen. Dominant Dolichoderinae and Opportunists were the only two groups that appeared in all habitats, and Opportunists were the most frequently sampled. Cryptic Species and Tropical Climate Specialists only occurred in backdunes. Bush areas supported more groups than other habitats (Fig. 6).
Ant and vegetation relationships

In intact foredunes, no significant correlation was detected between ant diversity and plant structure. In slacks, ant relative abundance was significantly correlated with plant richness $\left(P=0.0093, \mathrm{sr}^{2}\right.$ Type $\left.\mathrm{II}=0.212\right)$. In the open ground of backdunes, ant relative abundance was significantly correlated with plant cover $\left(P=0.0156, \mathrm{sr}^{2}\right.$ Type $\mathrm{II}=0.012), \quad$ plant richness $\quad\left(P=0.0009, \quad \mathrm{sr}^{2}\right.$ Type $\mathrm{II}=0.027)$ and stem maximum height $\left(P=0.0165, \mathrm{sr}^{2}\right.$ Type $\mathrm{II}=0.012$ ); and ant richness was significantly correlated with plant richness $\left(P=0.0072, \mathrm{sr}^{2}\right.$ Type $\mathrm{II}=0.156$ ). In the bush areas, ant relative abundance was significantly correlated with nearest trunk circumference $\left(P=0.0176, \mathrm{sr}^{2}\right.$ Type $\left.\mathrm{II}=0.177\right)$; ant richness was significantly correlated with nearest trunk circumference $\left(P=0.0080, \mathrm{sr}^{2}\right.$ Type $\left.\mathrm{II}=0.183\right)$ and lowest canopy height $\left(P=0.0286, \mathrm{sr}^{2}\right.$ Type $\left.\mathrm{II}=0.114\right)$.

\section{Disturbance}

Ant diversity was lower in degraded and restoration sites except old planted dunes (Fig. 7b). Community composition was different between intact and degraded dunes, and between reference and restoration dunes except the young planted sites in Mae's Beach (Fig. 7a). Specifically, (1) $D$. flavus and $F$. pruinosus were the most common species in intact foredunes, but population of $F$. pruinosus decreased in degraded sites. (2) Dominant species shifted from $D$. flavus to $F$. pruinosus after dunes were re-built. (3) Brachymyrmex patagonicus, which is invasive, became the most numerous species in old planted sites. Disturbance also influenced the composition of functional groups (Fig. 7c). Subordinate Camponotini and Generalized Myrmicinae were not detected, but Dominant Invasives were present in degraded and restoration areas. In addition, Cryptic Species, which were only found in backdunes, appeared in degraded, old planted, and re-built sites.

\section{Discussion}

Ant diversity, community composition and functional groups

Our study supports the hypothesis that community structure becomes more complex in later stages of succession, and species diversity increases upon moving inland from the water's edge and is representative of the various stages of succession on coastal dunes. The bush areas in the backdunes support the highest diversity and unique species assemblages. This is best explained by the presence of leaf litter and canopy acting as keystone structures (Tews et al. 
Table 1 Functional groups with assigned ant species

\begin{tabular}{|c|c|c|c|c|c|c|}
\hline \multirow[t]{2}{*}{ Functional group } & \multirow[t]{2}{*}{ Species } & \multicolumn{5}{|c|}{ Habitats } \\
\hline & & DFD & IFD & SL & $\mathrm{BO}$ & BB \\
\hline Dominant Dolichoderinae & Forelius pruinosus & $\mathrm{X}$ & $\mathrm{X}$ & $\mathrm{X}$ & $\mathrm{X}$ & $\mathrm{X}$ \\
\hline Dominant invasives & Solenopsis invicta & $\mathrm{X}$ & & & & \\
\hline \multirow[t]{3}{*}{ Subordinate Camponotini } & Camponotus impressus & & & & & $\mathrm{X}$ \\
\hline & Camponotus socius & & & & & $\mathrm{X}$ \\
\hline & Camponotus floridanus & & $\mathrm{X}$ & & & $\mathrm{X}$ \\
\hline \multirow[t]{7}{*}{ Generalized Myrmicinae } & Crematogaster ashmeadi & & & & & $\mathrm{X}$ \\
\hline & Crematogaster pilosa & & & & & $\mathrm{X}$ \\
\hline & Crematogaster pinicola & & & & & $\mathrm{X}$ \\
\hline & Monomorium minimum & & $X$ & & $X$ & $\mathrm{X}$ \\
\hline & Pheidole dentata & & & & $X$ & $\mathrm{X}$ \\
\hline & Pheidole floridana & & & & & $X$ \\
\hline & Pheidole morrisii & & & & & $\mathrm{X}$ \\
\hline Hot climate specialists & Pogonomyrmex badius & & & $X$ & $X$ & \\
\hline \multirow[t]{2}{*}{ Cold climate specialists } & Temnothorax texanus & & & $X$ & & \\
\hline & Temnothorax pergandei & & & & & $\mathrm{X}$ \\
\hline \multirow[t]{5}{*}{ Tropical climate specialists } & Cyphomyrmex rimosus & & & & & $\mathrm{X}$ \\
\hline & Trachymyrmex septentrionalis & & & & $X$ & $X$ \\
\hline & Pseudomyrmex ejectus & & & & & $\mathrm{X}$ \\
\hline & Pseudomyrmex gracilis & & & & & $X$ \\
\hline & Pseudomyrmex pallidus & & & & & $X$ \\
\hline \multirow[t]{9}{*}{ Cryptic species } & Stigmatomma pallipes & & & & & $\mathrm{X}$ \\
\hline & Brachymyrmex depilis & & & & & $X$ \\
\hline & Brachymyrmex patagonicus & $X$ & & & & $\mathrm{X}$ \\
\hline & Pheidole moerens & & & & & $\mathrm{X}$ \\
\hline & Pyramica dietrichi & & & & & $\mathrm{X}$ \\
\hline & Strumigenys talpa & & & & & $\mathrm{X}$ \\
\hline & Solenopsis carolinensis & & & & $X$ & $\mathrm{X}$ \\
\hline & Strumigenys louisianae & & & & & $\mathrm{X}$ \\
\hline & Hyроропега орасіоr & & & & & $\mathrm{X}$ \\
\hline \multirow[t]{15}{*}{ Opportunists } & Dorymyrmex bureni & & $X$ & $\mathrm{X}$ & $\mathrm{X}$ & $X$ \\
\hline & Dorymyrmex flavus & $\mathrm{X}$ & $\mathrm{X}$ & $\mathrm{X}$ & $X$ & \\
\hline & Tapinoma melanocephalum & & & & & $\mathrm{X}$ \\
\hline & Formica pallidefulva & & & & & $\mathrm{X}$ \\
\hline & Formica archboldi & & & & & $\mathrm{X}$ \\
\hline & Nylanderia arenivaga & $\mathrm{X}$ & $\mathrm{X}$ & $\mathrm{X}$ & $X$ & $\mathrm{X}$ \\
\hline & Nylanderia sp. & & & & & $\mathrm{X}$ \\
\hline & Nylanderia parvula & & & & & $\mathrm{X}$ \\
\hline & Nylanderia phantasma & & & & & $\mathrm{X}$ \\
\hline & Nylanderia wojciki & & & & & $\mathrm{X}$ \\
\hline & Aphaenogaster ashmeadi & & & & & $X$ \\
\hline & Aphaenogaster floridana & & & & & $\mathrm{X}$ \\
\hline & Cardiocondyla venustula & $\mathrm{X}$ & & & & \\
\hline & Odontomachus_brunneus & & & & & $X$ \\
\hline & Odontomachus haematodus & & & & & $\mathrm{X}$ \\
\hline
\end{tabular}

For each species, information is provided on its habitat(s): $D F D$ disturbed foredune, $I F D$ intact foredunes, $S L$ slack, $B O$ backdune (open ground), $B B$ backdune (bush) 


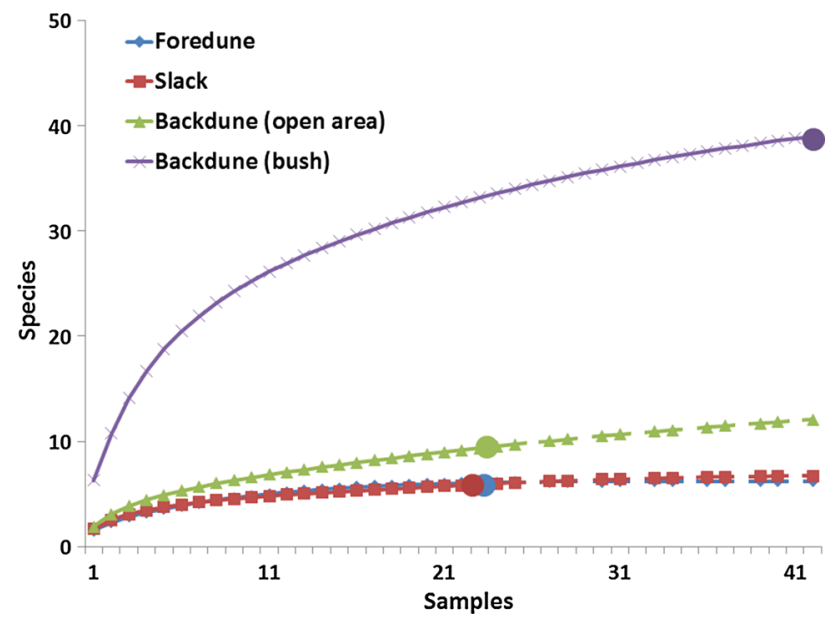

Fig. 3 Sample based rarefaction (solid lines) and extrapolation (dashed lines) curves for reference samples (filled circles) of the four habitats based on an average of series of 1,000 randomizations of the data. Only presence/absence data was used

Table 2 Species richness estimators with their standard deviations (SD) of four habitats of coastal dunes

\begin{tabular}{lcclcl}
\hline Habitats & Sobs & ICE & ICE (SD) & Chao 2 & $\begin{array}{l}\text { Chao 2 } \\
\text { (SD) }\end{array}$ \\
\hline $\begin{array}{l}\text { Foredune (intact) } \\
\text { Slack }\end{array}$ & 6 & 6.83 & 0.01 & 6 & 0.16 \\
$\begin{array}{l}\text { Backdune (open } \\
\text { ground) }\end{array}$ & 9 & 10.87 & 0.01 & 10 & 1.87 \\
$\begin{array}{l}\text { Backdune (bush) } \\
\text { ack }\end{array}$ & 39 & 47.77 & 0.01 & 44.79 & 5.04 \\
\hline
\end{tabular}

Sobs total number of species observed in the habitat, ICE incidencebased coverage estimator

2004). These structures may provide increased niche availability, a more stable environment, and increased moisture retention that all strongly influence the distributions of many other organisms (Pollet and Grootaert 1996; Sarig et al. 1999; Finke and Snyder 2008; Carpintero et al. 2011; Schirmel and Buchholz 2011).

All known functional groups of ants can be found in the coastal dunes with the exception of Specialist Predators. The Opportunists was the most diverse functional group across all of the different habitats. This is due to the ability of Opportunist ants to be able to withstand consistent, natural disturbance (such as sand burial and strong winds) on coastal dunes. Subordinate Camponotini, Tropical Climate Specialists, most Generalist Myrmicinae, and most Cryptic Species were found only in the bush areas of backdunes due to the complexity of the vegetation structure and the available nesting sites provided by the canopy and leaf litter. The disappearance of the Hot Climate Specialists from the bush areas is expected because they are associated with open, hot, and stressed habitats (Pfeiffer et al. 2003; Gomez and Abril 2011). One unexpected finding was a cold climate specialist species (T. texanus) located in the slack at Grayton Beach State Park. These ants are normally associated with mesic or shady environments (So and Chu 2010; Beaumont et al. 2012). Grayton Beach State Park has a narrow slack area very close to the backdunes. Because of this, we believe T. texanus is nesting in the bush areas immediately next to the slack. Further collections need to be made to confirm this.

Ant community and vegetation structure

Vegetation is one of the most important factors that influence ant distribution at local, regional, and continental scales (Gotelli and Ellison 2002). Vegetation structure alters food resources, nesting sites, and micro-climate conditions (Boomsma and Devries 1980; Rico-Gray et al. 1998; Andersen et al. 2006; Hoffmann and James 2011), and further regulates ant diversity, behavior, and interactions among species (Huxley and Cutler 1991; Botes et al. 2006; Wilkinson and Feener 2007; Hill et al. 2008). The general assumption is that species diversity is positively associated with vegetation complexity (Bonte et al. 2002; Tews et al. 2004; Sarty et al. 2006). However, the local environment, habitat type, plant composition, disturbance, as well as ant behavior and life history make the outcomes highly variable (Bestelmeyer and Schooley 1999; Kotze and Samways 1999; Retana and Cerdá 2000; French and Major 2001; Lassau and Hochuli 2004). In addition, most previous research has been conducted in environments strongly associated with anthropogenic disturbances such as fire and grazing, and less attention has been paid to more natural habitats (Ruiz-Jaen and Aide 2005; Jiménes-Valverde and Lobo 2007; Gibb and Parr 2010).

In intact coastal dunes, we found vegetation structure significantly influenced ant community. On open areas, increased stem height, plant richness and cover are related to higher ant diversity. This may be due to increased niche opportunities or improved micro-climates caused by the larger three-dimensional structure associated with the various kinds of vegetation (Lawton 1983; Gardner et al. 1995; Vasconcelos et al. 2008; Wenninger and Inouye 2008; Cardoso et al. 2010; Wiezik et al. 2011). More importantly, it also may be an indicator of an area experiencing less stress. Vegetation may also influence ants indirectly. Higher diversity of plants may attract other arthropods, which function as food resources, competitors, or predators of ants (Hansen 2000). In addition, our research only covered a range of plant cover from zero to $58 \%$, and plant richness from zero to six in a single plot. Further studies are needed to determine if the relationship between ant diversity and plants is maintained at more 
Fig. 4 Rényi diversity profiles for the different habitats of coastal dunes along Gulf of Mexico

Fig. 5 Detrended Correspondence Analysis (DCA) for ant species composition based on quadrat sampling in four dune habitats, only presence/absence data was used, each dot represented the species composition in each plot
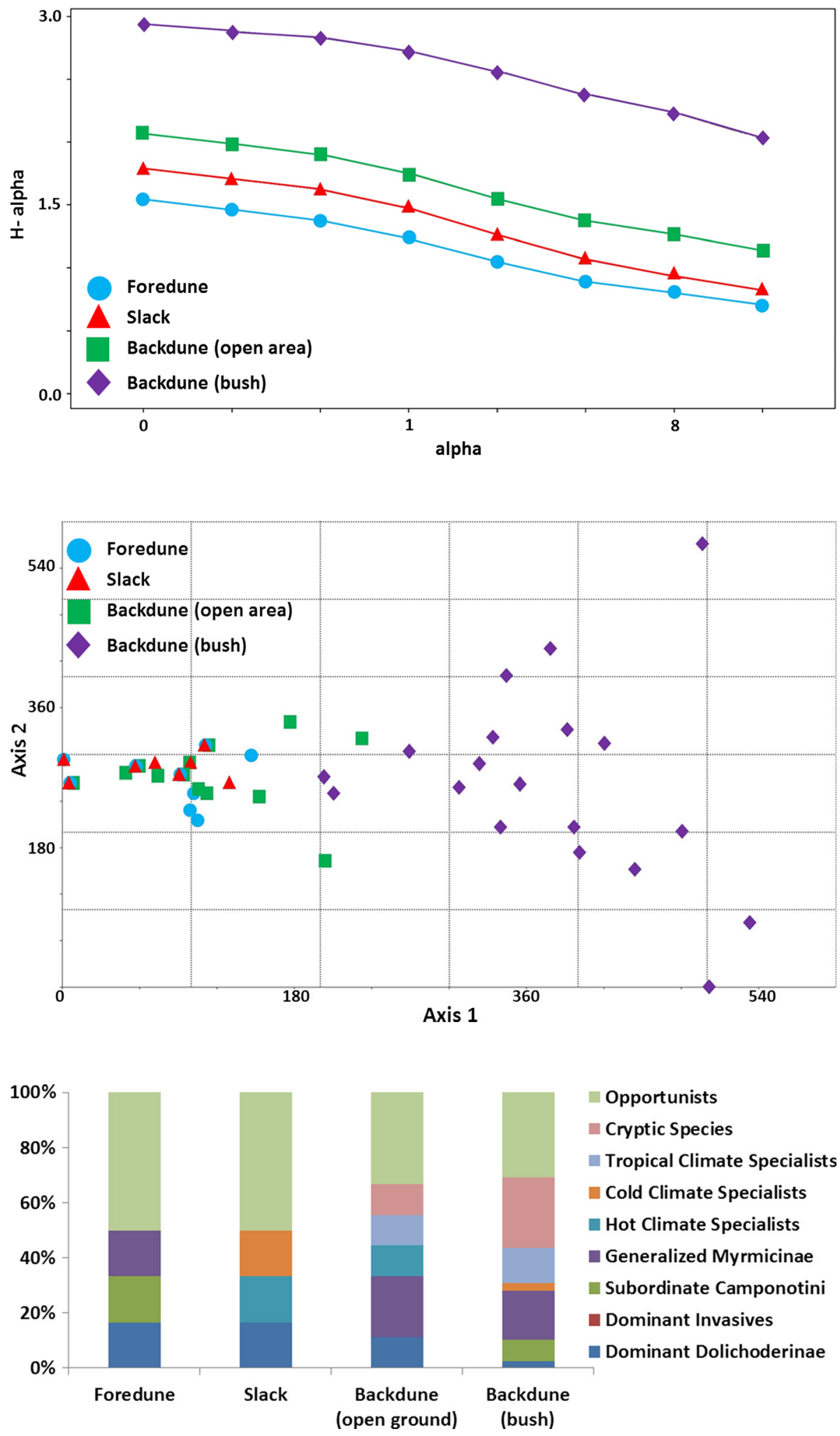

Fig. 6 Functional group profiles of coastal dune ant fauna from four habitats. Data are relative contributions of each functional group to total species richness. (Color figure online) complex vegetation structure (Lassau and Hochuli. 2004; Arnan et al. 2007; Hill et al. 2008). Although ant community composition is similar among the open area of dunes, the relationship between ant diversity and vegetation structure is not consistent in these habitats. Higher correlations are found in the later succession stages, this 


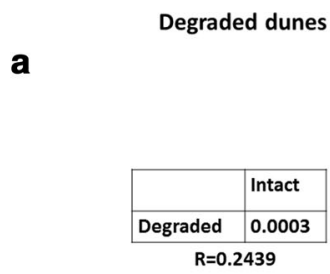

b
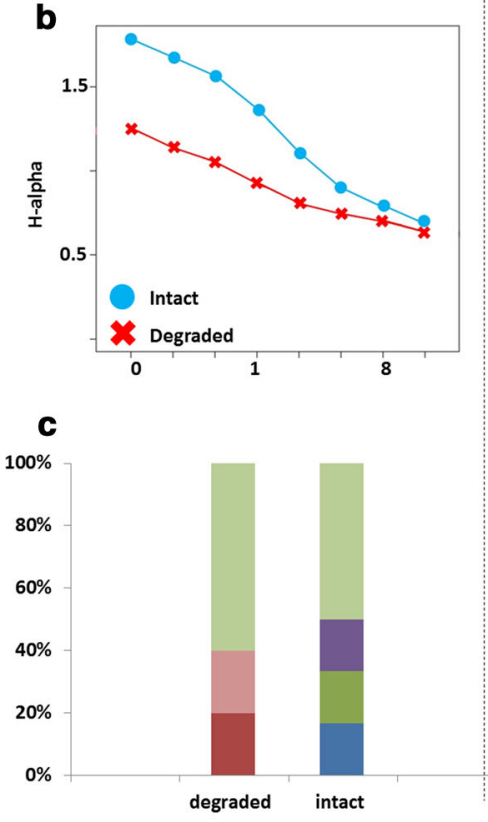

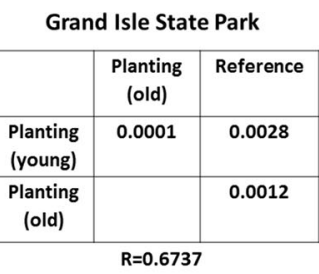

Mae and Cameron Beach

\begin{tabular}{|l|c|c|}
\hline & Re-built & Reference \\
\hline $\begin{array}{l}\text { Planting } \\
\text { (young) }\end{array}$ & 0.0001 & 0.0657 \\
\hline Re-built & & 0.0005 \\
\hline \multicolumn{2}{|c|}{$R=0.5577$} \\
\hline
\end{tabular}
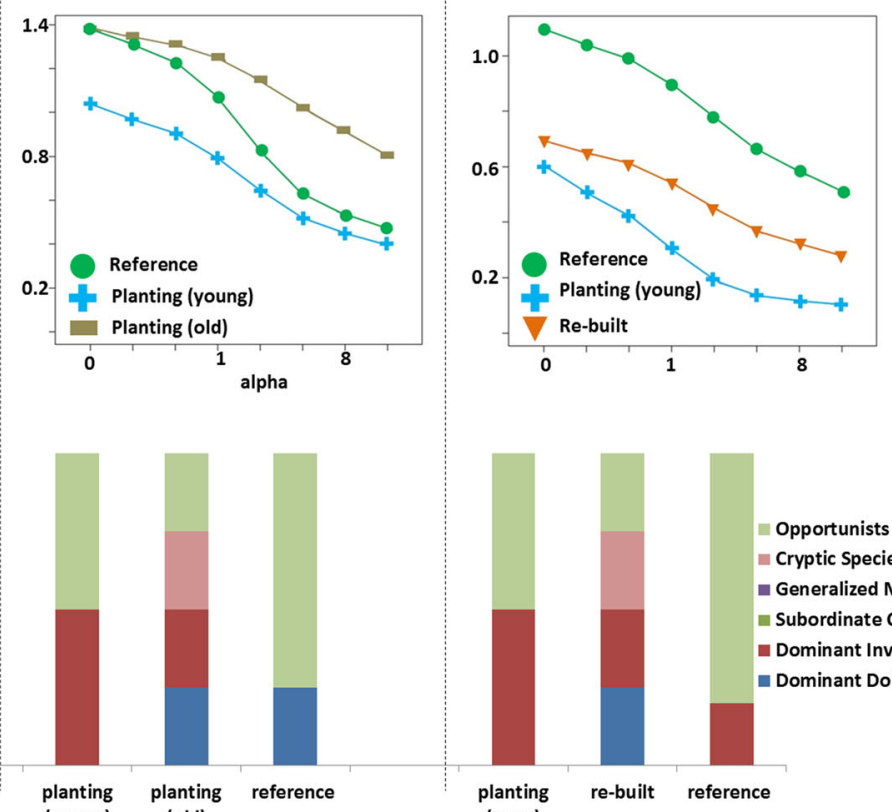

old)

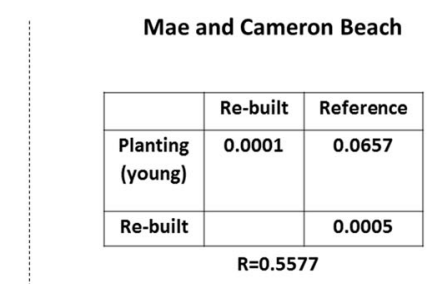

(young)

Fig. 7 a ANOSIM results between intact and degraded dunes, and between reference and restoration dunes. b Rényi diversity profiles, and c Functional group profiles of intact, degraded, reference and restoration dunes. (Color figure online)

may be due to the decreasing environmental stress from foredune to backdune. However, manipulative experimental approaches are needed to confirm this assumption and to reveal other possible explanations (Luque and Lopez 2007).

Ant diversity increases sharply when bushes inhabit the backdunes. Whereas no associations were detected between ant diversity and leaf litter, which is thought to play an important role in structuring ant composition (Bestelmeyer and Schooley 1999; Cardoso et al. 2010); ant richness was higher under thicker bushes. The thicker trunk may reflect the age of bushes as well as the age of sampling site as older bushes will have a larger trunk circumference. The sites with longer succession time may be more stable and support more species (Maun 2009).

\section{Disturbance}

Both taxonomic composition and functional groups respond to disturbance. D. flavus and F. pruinosus are the most common species in intact foredunes. They are active in open sandy places and can forage on hot ground which may be too hot for other ants (Antweb.org; Valone and Kaspari 2005; Warriner et al. 2008). In disturbed areas, the population of one of these two species decreased depending upon the type of disturbance. Retrogression of primary succession can be caused by disturbance, which may be one explanation for the changes in these ant populations (Kaufmann 2001). However, testing succession processes and hypotheses is beyond the scope of this paper. More information is needed in order to determine which one of these two species is the pioneer and how disturbance resets the ant succession on dunes.

The most obvious change of functional groups is the positive association between S. invicta (Dominant Invasives) with disturbance. This is predictable because, when present, this species generally occurs in anthropogenically modified areas. In addition, the disappearance of Generalized Myrmicinae is also expected because this group is sensitive to disturbances (Gomez et al. 2003a, b; Castracani et al. 2010). Although Cryptic Species have previously been shown to have a negative response to disturbance (Hoffmann and Anderson 2003), their wide occurrence in disturbed areas of our study is not surprising. This is 
because the only species belonging to this group in foredunes is B. patagonicus, a ubiquitous, introduced species known nests close to urban areas (MacGown et al. 2007). It is difficult to explain why Dominant Dolichoderinae were not detected in some locations. Our original hypothesis was Opportunists act as a pioneer group that first colonize in the early succession stage such as the planted beach and re-built dunes, followed by Dominant Dolichderinae that are shown to increase in abundance in moderately disturbed sites (Andersen and Majer 2004). However, the results don't support this assumption. More detailed research is needed not only to study the relationship between disturbance and functional groups, but also to test whether the responses we found are consistent in other dune habitats worldwide.

Our sites in degraded dunes contain well-protected foredunes that are surrounded by areas of high humanmediated disturbance. Even though few anthropogenic disturbances occur directly on those foredunes, ant community composition between intact and degraded foredunes is different. This is likely caused by species from the adjacent, disturbed environments entering the dunes and outcompeting native dune species or a loss of native dune species due to the loss of the slack and backdunes (Golden and Crist 2000; Crist 2009). In either circumstance, our research indicates the importance of (1) providing preservation areas large enough to encompass all habitats on the coastal dunes, and (2) reducing the isolation of dune habitats.

Planted dunes, not only the beach but also the backdunes, are a major issue in coastal restoration today. The planted grass can hold sand and trap windblown sediment, which are essential for building new dunes. There is a growing interest in evaluation of the recovery of biodiversity and ecosystem functions in restoration areas (Lamb et al. 2005). However, most studies focus on vegetation selection and monitoring the survival and growth of planted grass, and few mentioned how planting affects invertebrates. Our research showed that the ant community changed in planted sites, which may be due to the change in vegetation structure (high plant cover and decreased plant diversity) caused by the monocultures of $P$. amarum (Fig. 2d). To determine more suitable planting strategies, such as using a variety of species instead of planting a single one, more studies are needed to detangle how planting activities affect other invertebrates as well as the whole dune ecosystem.

\section{Conservation}

General ecological and conservation theories together with detailed descriptions of local environments, habitats and vegetation types, and the reaction of local species to habitat changes should be considered when making protection policies (Dauber et al. 2006). Our research indicates that plant structure significantly influences ant composition on coastal dunes. In the northern Gulf of Mexico, invasive species, dune restoration activities, and oil pollution modify or simplify the plant composition in dunes (Cousins et al. 2010; Grafals-Soto 2012; Hooper-Bùi, unpubl.). In addition, the frequency and strength of hurricanes and storm surge events have increased and will continue increasing in the future because of global climate change (Trenberth 2005; Webster et al. 2005). Hurricanes and storm surge are predicted to change the vegetation across the whole dune system (Gornish and Miller 2010). The changed vegetation structure may affect ant diversity, and further influence the dune ecosystem due to the important ecological roles that the ants play.

Ant diversity increases with accumulating complexity and richness of vegetation and reduction of stressors. In the bush areas of the backdunes, increased ant species diversity results mainly from the existence of the canopy and leaf litter, which provide complexity and buffer from stress. These structures provide increased niche space and play crucial roles in supporting high diversity of not only ants, but also other fauna (Hansen 2000; Ruiz-Jaen and Aide 2005; Silva et al. 2011). Our study emphasizes the importance of protecting backdunes, which act as critical habitats but are frequently disturbed in northern Gulf of Mexico (Pries et al. 2009). Additionally, backdunes are important for wind attenuation and to protect inland areas from storm surge.

Our study highlights the value of ants as indicators in coastal dune ecosystem because (1) their diversity and occurrence is high in dune habitats, (2) they are easy to sample, and (3) both community composition and functional groups are sensitive to human disturbances, especially functional groups which are useful for assessing environmental changes in land management areas (Andersen et al. 2004; Narendra et al. 2011).

Acknowledgments We are indebted to Rachel Strecker for her technical help. We thank Allen Andersen (SCIRO Darwin Laboratories), Nathan Sanders (Department of Ecology and Evolutionary Biology, The University of Tennessee), Patrick Hesp (Department of Geography and Anthropology, Louisiana State University), Kyle Harms (Department of Biology, Louisiana State University), James Geaghan (Department of Experimental Statistics, Louisiana State University), Christopher Carlton (Department of Entomology, Louisiana State University), and Gregg Henderson (Department of Entomology, Louisiana State University) for helpful comments on this paper. We also thank Joe MacGown (Department of Entomology and Plant Pathology, Mississippi State University) and James Trager (Missouri Botanical Garden) for confirmation of the identity of ant species. Thanks to National Park Service, Florida State Parks, and Louisiana Department of Wildlife and Fisheries for facilitating work at those locations. We also thank Theresa Crupi, Matthew Landry, and Melissa Ausburn for their technical assistance. This research was 
made possible in part by a grant from BP/The Gulf of Mexico Research Initiative, and in part by the Northern Gulf Institute grant to LMHB. The funders had no role in study design, data collection and analysis, decision to publish, or preparation of the manuscript.

Open Access This article is distributed under the terms of the Creative Commons Attribution License which permits any use, distribution, and reproduction in any medium, provided the original author(s) and the source are credited.

\section{References}

Agosti D, Majer J, Alonso LE, Schultz TR (2000) Ants: standard methods for measuring and monitoring biodiversity. Smithsonian Institution Press, Washington

Andersen AN (1997) Functional groups and patterns of organization in North American ant communities: a comparison with Australia. J Biogeogr 24(4):433-460

Andersen AN, Majer JD (2004) Ants show the way Down Under: invertebrates as bioindicators in land management. Front Ecol Environ 2(6):291-298

Andersen AN, Morrison S, Belbin L (1996) The role of ants in minesite restoration in the Kakadu region of Australia's northern Territory, with particular reference to their use as bioindicators. Final report to the Environmental Research Institute of the Supervising Scientists, Australia

Andersen AN, Hoffmann BD, Muller WJ, Griffiths AD (2002) Using ants as bioindicators in land management: simplifying assessment of ant community responses. J Appl Ecol $39(1): 8-17$

Andersen AN, Fisher A, Hoffmann BD, Read JL, Richards R (2004) Use of terrestrial invertebrates for biodiversity monitoring in Australian rangelands, with particular reference to ants. Austral Ecol 29(1):87-92

Andersen AN, Hertog T, Woinarski JCZ (2006) Long-term fire exclusion and ant community structure in an Australian tropical savanna: congruence with vegetation succession. J Biogeogr 33(5):823-832

Antweb http://www.antweb.org v5.1.32. 2012. Retrieved 13 Nov 2013

Arnan X, Rodrigo A, Retana J (2007) Uncoupling the effects of shade and food resources of vegetation on Mediterranean ants: an experimental approach at the community level. Ecography 30(2):161-172

Beaumont KP, Mackay DA, Whalen MA (2012) The effects of prescribed burning on epigaeic ant communities in eucalypt forest of South Australia. For Ecol Manage 271:147-157

Bestelmeyer BT, Schooley RL (1999) The ants of the southern Sonoran desert: community structure and the role of trees. Biodivers Conserv 8(5):643-657

Bonte D, Maes D (2008) Trampling affects the distribution of specialised coastal dune arthropods. Basic Appl Ecol 9:726-734

Bonte D, Baert L, Maelfait JP (2002) Spider assemblage structure and stability in a heterogeneous coastal dune system (Belgium). J Arachnol 30(2):331-343

Bonte D, Dekoninck W, Provoost S, Cosijns E, Hoffmann M (2003) Microgeographical distribution of ants (Hymenoptera: Formicidae) in coastal dune grassland and their relation to the soil structure and vegetation. Anim Biol 54(4):367-377

Bonte D, Criel P, Vanhoutte L, VanThournout I, Maelfait JP (2004) The importance of habitat productivity, stability and heterogeneity for spider species richness in coastal grey dunes along the North Sea and its implications for conservation. Biodivers Conserv 13(11):2119-2134
Boomsma JJ, Devries A (1980) Ant species distribution in a sandy coastal plain. Ecol Entomol 5(3):189-204

Boomsma JJ, Van Loon AJ (1982) Structure and diversity of ant communities in successive coastal dune valleys. J Anim Ecol 51(3):957-974

Botes A, McGeoch MA, Robertson HG, van Niekerk A, Davids HP, Chown SL (2006) Ants, altitude and change in the northern Cape Floristic Region. J Biogeogr 33(1):71-90

Cardoso DC, Sobrinho TG, Schoereder JH (2010) Ant community composition and its relationship with phytophysiognomies in a Brazilian Restinga. Insect Soc 57(3):293-301

Carpintero S, Reyes-Lopez J, Luque GM (2011) Ant community structure under Retama sphaerocarpa shrubs in a semi-arid environment. Entomol Sci 14(2):147-153

Castracani C, Grasso DA, Fanfani A, Mori A (2010) The ant fauna of Castelporziano Presidential Reserve (Rome, Italy) as a model for the analysis of ant community structure in relation to environmental variation in Mediterranean ecosystems. J Insect Conserv 14(6):585-594

Claudino-Sales V, Wang P, Horwitz MH (2008) Factors controlling the survival of coastal dunes during multiple hurricane impacts in 2004 and 2005: Santa Rosa barrier island, Florida. Geomorphology 95(3-4):295-315

Colwell RK (2013) EstimateS: statistical estimation of species richness and shared species from samples. Version 9. User's Guide and application published at: http://purl.oclc.org/estimates

Cousins M, Briggs J, Gresham C, Whetstone J, Whitwell T (2010) Beach Vitex (Vitex rotundifolia): an invasive coastal species. Invasive Plant Sci Manag 3(3):340-345

Crist TO (2009) Biodiversity, species interactions, and functional roles of ants (Hymenoptera: Formicidae) in fragmented landscapes: a review. Myrmecol News 12:3-13

Crutsinger GM, Sanders NJ (2005) Aphid-tending ants affect secondary users in leaf shelters and rates of herbivory on Salix hookeriana in a coastal dune habitat. Am Midl Nat 154(2):296-304

Cuautle M, Rico-Gray V, Diaz-Castelazo C (2005) Effects of ant behaviour and presence of extrafloral nectaries on seed dispersal of the Neotropical myrmecochore Turnera ulmifolia L. (Turneraceae). Biol J Linn Soc 86(1):67-77

Dauber J, Bengtsson J, Lenoir L (2006) Evaluating effects of habitat loss and land-use continuity on ant species richness in seminatural grassland remnants. Conserv Biol 20(4):1150-1160

Davis RA Jr, Fitzgerald D (2004) Beaches and coasts. Blackwell, Oxford

Dech JP, Maun MA (2005) Zonation of vegetation along a burial gradient on the leeward slopes of Lake Huron sand dunes. Can J Bot 83(2):227-236

Duffy E (1968) An ecological analysis of the spider fauna of sand dunes. J Anim Ecol 37:641-674

El Banna MM, Mahmoud M (2008) Vulnerability and fate of a coastal sand dune complex, Rosetta-Idku, northwestern Nile Delta, Egypt. Environ Geol 54(6):1291-1299

Feagin RA, Sherman DJ, Grant WE (2005) Coastal erosion, global sea-level rise, and the loss of sand dune plant habitats. Front Ecol Environ 3(7):359-364

Finke DL, Snyder WE (2008) Niche partitioning increases resource exploitation by diverse communities. Science 321:1488-1490

French K, Major RE (2001) Effect of an exotic Acacia (Fabaceae) on ant assemblages in South African fynbos. Austral Ecol 26(4):303-310

Gardner S, Cabido MR, Valladares GR, Diaz S (1995) The influence of habitat structure on arthropod diversity in Argentine semi-arid Chaco forest. J Veg Sci 6(3):349-356

Gaylard A, McLachlan A, Kerley GIH (1995) Faunal changes along a vegetation gradient in the Alexandria Coastal Dunefield, South Africa. Afr Zool 30:23-28 
Gibb H, Parr CL (2010) How does habitat complexity affect ant foraging success? A test using functional measures on three continents. Oecologia 164(4):1061-1073

Golden DM, Crist TO (2000) Experimental effects of habitat fragmentation on rove beetles and ants: patch area or edge? Oikos 90(3):525-538

Gomez C, Abril S (2011) Selective logging in public pine forests of the central Iberian Peninsula: effects of the recovery process on ant assemblages. For Ecol Manage 262(6):1061-1066

Gomez C, Casellas D, Oliveras J, Bas JM (2003a) Structure of ground-foraging ant assemblages in relation to land-use change in the northwestern Mediterranean region. Biodivers Conserv 12(10):2135-2146

Gomez C, Casellas D, Oliveras J, Bas JM (2003b) Structure of ground-foraging ant assemblages in relation to land-use change in the northwestern Mediterranean region. Biodivers Conserv 12:2135-2146

Gornish ES, Miller TE (2010) Effects of storm frequency on dune vegetation. Glob Change Biol 16(10):2668-2675

Gotelli NJ, Ellison AM (2002) Biogeography at a regional scale: determinants of ant species density in new England bogs and forests. Ecology 83(6):1604-1609

Gotelli NJ, Ellison AM (2012) A primer of Ecological Statistics, 2nd edn. Sinauer Associates, Sunderland

Gotelli NJ, Ellison AM, Dunn RR, Sanders NJ (2011) Counting ants (Hymenoptera: Formicidae): biodiversity sampling and statistical analysis for myrmecologists. Myrmecol News 15:13-19

Grafals-Soto R (2012) Effects of sand fences on coastal dune vegetation distribution. Geomorphology 145:45-55

Grunewald R (2006) Assessment of damages from recreational activities on coastal dunes of the southern Baltic Sea. J Coast Res 22(5):1145-1157

Hammer Ø, Harper DAT, Ryan PD (2001) PAST: paleontological statistics software package for education and data analysis. Palaeontol Electron 4(1):1-9

Hansen RA (2000) Effects of habitat complexity and composition on a diverse litter microarthropod assemblage. Ecology 81(4):1120-1132

Hesp PA (1991) Ecological processes and plant adaptations on coastal dunes. J Arid Environ 21:165-191

Hill JG, Summerville KS, Brown RL (2008) Habitat associations of ant species (Hymenoptera: Formicidae) in a heterogeneous Mississippi landscape. Environ Entomol 37(2):453-463

Hoffmann BD, Anderson AN (2003) Responses of ants to disturbance in Australia, with particular reference to functional groups. Austral Ecol 28(4):444-464

Hoffmann BD, James CD (2011) Using ants to manage sustainable grazing: dynamics of ant faunas along sheep grazing gradients conform to four global patterns. Austral Ecol 36(6):698-708

Hoffmann BD, Griffiths AD, Andersen AN (2000) Responses of ant communities to dry sulfur deposition from mining emissions in semi-arid tropical Australia, with implications for the use of functional groups. Austral Ecol 25(6):653-663

Hölldobler B, Wilson EO (1990) The Ants. The Belknap Press of Harvard University Press Cambridge, Cambridge

Huxley CR, Cutler DF (1991) Ant-plant interactions. Oxford University Press, Oxford

Isermann M (2005) Soil $\mathrm{pH}$ and species diversity in coastal dunes. Plant Ecol 178(1):111-120

Isermann M (2011) Patterns in species diversity during succession of coastal dunes. J Coast Res 27(4):661-671

Jackson DWT, Cooper JAG (2011) Coastal dune fields in Ireland: rapid regional response to climatic change. J Coast Res Special Issue 64:293-297

Jiménes-Valverde A, Lobo JM (2007) Determinants of local spider (Araneidae and Thomisidae) species richness on a regional scale: climate and altitude vs. habitat structure. Ecol Entomol 31(1):113-122

Johnson AF (1997) Rates of vegetation succession on a coastal dune system in northwest Florida. J Coast Res 13(2):373-384

Kaufmann R (2001) Invertebrate succession on alpine glacier foreland. Ecology 82(8):2261-2278

Kerley GIH, McLachlan A, Castley JG (1996) Diversity and dynamics of bushpockets in the Alexandria Coastal Dunefield, South Africa. Landsc Urban Plan 34(3-4):255-266

Kindt R, Coe R (2005) Tree diversity analysis A manual and software for common statistical methods for ecological and biodiversity studies. World Agroforestry Centre (ICRAF), Nairobi

Kindt R, Van Damme P, Simons AJ (2006) Tree diversity in western Kenya: using profiles to characterise richness and evenness. Biodivers Conserv 15:1253-1270

King JR, Andersen AN, Cutter AD (1998) Ants as bioindicators of habitat disturbance: validation of the functional group model for Australia's humid tropics. Biodivers Conserv 7(12):1627-1638

Kotze DJ, Samways MJ (1999) Invertebrate conservation at the interface between the grassland matrix and natural Afromontane forest fragments. Biodivers Conserv 8:1339-1363

Lamb D, Erskine PD, Parrotta JA (2005) Restoration of degraded tropical forest landscapes. Science 310:1628-1632

Landi M, Ricceri C, Angiolini C (2012) Evaluation of dune rehabilitation after 95 years by comparison of vegetation in disturbed and natural sites. J Coast Res 28(5):1130-1141

Lane C, Wright SJ, Roncal J, Maschinski J (2008) Characterizing environmental gradients and their influence on vegetation zonation in a subtropical coastal sand dune system. J Coast Res 24(4C):213-224

Lassau SA, Hochuli DF (2004) Effects of habitat complexity on ant assemblages. Ecography 27(2):157-164

Lawton JH (1983) Plant architecture and the diversity of phytophagous insects. Annu Rev Entomol 28:23-39

Lehouck VS, Bonte DB, Dekoninck W, Maelfait JPE (2004) Trophobiotic relationships between ants (Hymenoptera: Formicidae) and Tettigometridae (Hemiptera: Fulgoromorpha) in the grey dunes of Belgium. Eur J Entomol 101(4):547-553

Lichter J (1998) Primary succession and forest development on coastal Lake Michigan sand dunes. Ecol Monogr 68(4):487-510

Lithgow D, Martinez ML, Gallego-Fernandez JB, Hesp PA, Flores P, Gachuz S, Rodriguez-Revelo N, Jimenez-Orocio O, MendozaGonzalez G, Alvarez-Molina LL (2013) Linking restoration ecology with coastal dune restoration. Geomorphology 199:214-224

Luque GM, Lopez JR (2007) Effect of experimental small-scale spatial heterogeneity on resource use of a Mediterranean groundant community. Acta Oecol 32(1):42-49

MacGown JA, Hill JG, Deyrup MA (2007) Brachymyrmex patagonicus (Hymenoptera: Formicidae), an emerging pest species in the southeastern United States. Fla Entomol 90:457-464

Majer JD (1983) Ants: bio-indicators of minesite rehabilitation, landuse, and land conservation. Environ Manage 7:375-383

Marchante E, Kjoller A, Struwe S, Freitas H (2008) Short- and longterm impacts of Acacia longifolia invasion on the belowground processes of a Mediterranean coastal dune ecosystem. Appl Soil Ecol 40(2):210-217

Maun MA (2009) The biology of coastal sand dunes. Oxford University Press, New York

Maun MA, Perumal J (1999) Zonation of vegetation on lacustrine coastal dunes: effects of burial by sand. Ecol Lett 2:14-18

Miller TE, Gornish ES, Buckley HL (2010) Climate and coastal dune vegetation: disturbance, recovery, and succession. Plant Ecol 206(1):97-104

Mondino EA, Tavares OCH, Figueira AF, Souza NB, Berbara RLL (2011) Nematode communities in different vegetation types in a 
coastal ecosystem of Restinga in Brazil. Nematropica 14(2):229-239

Morrison LW (2002) Interspecific competition and coexistence between ants and land hermit crabs on small Bahamian islands. Acta Oecol 23:223-229

Narendra A, Gibb H, Ali T (2011) Structure of ant assemblages in Western Ghats, India: role of habitat, disturbance and introduced species. Insect Conserv Divers 4(2):132-141

Oliveira PS, Rico-Gray V, Diaz-Castelazo C, Castillo-Guevara C (1999) Interaction between ants, extrafloral nectaries and insect herbivores in neotropical coastal sand dunes: herbivore deterrence by visiting ants increases fruit set in Opuntia stricta (Cactaceae). Funct Ecol 13(5):623-631

Oostermeijer JGB (1989) Myrmecochory in Polygala vulgaris L., Luzula campestris(L.) D.C. and Viola curtisii Forster in a Dutch dune area. Oecologia 78(3):302-311

Pfeiffer M, Chimedregzen L, Ulykpan K (2003) Community organization and species richness of ants (Hymenoptera: Formicidae) in Mongolia along an ecological gradient from steppe to Gobi desert. J Biogeogr 30(12):1921-1935

Pollet M, Grootaert P (1996) An estimation of the natural value of dune habitats using Empidoidea (Diptera). Biodivers Conserv 5(7):859-880

Powell JA (1981) Endangered habitats for insects: California coastal sand dunes. Atala 6:41-55

Pries AJ, Branch LC, Miller DL (2009) Impact of hurricanes on habitat occupancy and spatial distribution of beach mice. J Mammal 90(4):841-850

Provoost S, Jones MLM, Edmondson SE (2011) Changes in landscape and vegetation of coastal dunes in northwest Europe: a review. J Coast Conserv 15(1):207-226

R Core Team (2013) R: a language and environment for statistical computing. R Foundation for Statistical Computing, Vienna, Austria. ISBN:3-900051-07-0. http://www.R-project.org/

Rajaniemi TK, Allison VJ (2009) Abiotic conditions and plant cover differentially affect microbial biomass and community composition on dune gradients. Soil Biol Biochem 41(1):102-109

Retana J, Cerdá X (2000) Patterns or diversity and composition of Mediterranean ground ant communities tracking spatial and temporal variability in the thermal environment. Oecologia 123:436-444

Rico-Gray V, Garcia-Franco JG, Palacios-Rios M, Diaz-Castelazo C, Parra-Tabla V, Navarro JA (1998) Geographical and seasonal variation in the richness of ant-plant interactions in Mexico. Biotropica 30(2):190-200

Rico-Gray V, Oliveira PS, Parra-Tabla V, Cuautle M, Díaz-Castelazo C (2007) Ant-plant interactions: their seasonal variation and effect on plant fitness. In: Martínez ML, Psuty NP (eds) Coastal dunes: ecology and conservation. Springer, Berlin, pp 221-239

Ricotta C (2003) On parametric evenness measures. J Theor Biol 222:189-197

Ruiz-Jaen MC, Aide TM (2005) Vegetation structure, species diversity, and ecosystem processes as measures of restoration success. For Ecol Manage 218:159-173

Sarig S, Fliessbach A, Steinberger Y (1999) Soil microbial biomass under the canopy of coastal sand dune shrubs. Arid Soil Res Rehab 13(1):75-80

Sarty M, Abbott KL, Lester PJ (2006) Habitat complexity facilitates coexistence in a tropical ant community. Oecologia 149:465-473
SAS Institute Inc. (2011) Base SAS ${ }^{\circledR} 9.3$ Procedures guide. SAS Institute Inc., Cary

Schirmel J, Buchholz S (2011) Response of carabid beetles (Coleoptera: Carabidae) and spiders (Araneae) to coastal heathland succession. Biodivers Conserv 20(7):1469-1482

Schuldt A, Assmann T (2010) Invertebrate diversity and national responsibility for species conservation across Europe-a multitaxon approach. Biol Conserv 143:2747-2756

Silva PSD, Bieber AGD, Correa MM, Leal IR (2011) Do leaf-litter attributes affect the richness of leaf-litter ants? Neotrop Entomol 40(5):542-547

Slawska M (1997) Succession of Collembola in an active deflation hollow in Slowinski National Park. Pedobiolgia 41(1-3):139-144

So WY, Chu LM (2010) Ant assemblages on rehabilitated tropical landfills. Biodivers Conserv 19(13):3685-3697

Tews J, Brose U, Grimm V, Tielborger K, Wichmann MC, Schwager M, Jeltsch F (2004) Animal species diversity driven by habitat heterogeneity/diversity: the importance of keystone structures. J Biogeogr 31(1):79-92

Tóthmérész B (1995) Comparison of different methods for diversity ordering. J Veg Sci 6:283-290

Trenberth K (2005) Uncertainty in hurricanes and global warming. Science 308:1753-1754

Valone TJ, Kaspari M (2005) Interactions between granivorous and omnivorous ants in a desert grassland: results from a long-term experiment. Ecol Entomol 30(1):116-121

van der Maarel E (2003) Some remarks on the functions of the European coastal ecosystems. Phytocoenologia 33(2-3):187-202

Vasconcelos HL, Leite MF, Vilhena JMS, Lima AP, Magnusson WE (2008) Ant diversity in an Amazonian savanna: relationship with vegetation structure, disturbance by fire, and dominant ants. Austral Ecol 33(2):221-231

Warriner RA Jr, Gold RE, Austin JW (2008) Ecology of Dorymyrmex flavus (Hymenoptera: Formicidae) in Central Texas, including aspects of competition with Solenopsis invicta Buren. Sociobiology 52:229-250

Webster PJ, Holland GJ, Curry JA, Chang HR (2005) Changes in tropical cyclone number, duration, and intensity in a warming environment. Science 309:1844-1846

Wenninger EJ, Inouye RS (2008) Insect community response to plant diversity and productivity in a sagebrush-steppe ecosystem. $\mathrm{J}$ Arid Environ 72:24-33

Wetterer JK, Wood LD, Johnson C, Krahe H, Fitchett S (2007) Predaceous ants, beach replenishment, and nest placement by sea turtles. Environ Entomol 36(5):1084-1091

Wiezik M, Wiezikova A, Svitok M (2011) Vegetation structure, ecological stability, and low-disturbance regime of abandoned dry grasslands support specific ant assemblages in Central Slovakia. Tuexenia 31:301-315

Wilkinson EB, Feener DH (2007) Habitat complexity modifies antparasitoid interactions: implications for community dynamics and the role of disturbance. Oecologia 152:151-161

Wilson JB, Sykes MT (1999) Is zonation on coastal sand dunes determined primarily by sand burial or by salt spray? A test in New Zealand dunes. Ecol Lett 2:233-236

Yoshitake S, Nakatsubo T (2008) Changes in soil microbial biomass and community composition along vegetation zonation in a coastal sand dune. Aust J Soil Res 46(4):390-396 